\title{
Influence of distillation time and sample mass on sulfur dioxide analysis in passion fruit juice through Monier-Williams method
}

\author{
Anita Akiko TAKAHASHI ${ }^{1}$, Maristela Satou MARTINS ${ }^{1}$, Jussara Carvalho de Moura DELLA TORRE ${ }^{1}$, \\ Camila Cardoso de OLIVEIRA ${ }^{1}$, Daniel GRANATO ${ }^{2 *}$
}

\begin{abstract}
This study aimed to evaluate the effect of the distillation time and the sample mass on the total $\mathrm{SO}_{2}$ content in integral passion fruit juice (Passiflora sp). For the $\mathrm{SO}_{2}$ analysis, a modified version of the Monier-Williams method was used. In this experiment, the distillation time and the sample mass were reduced to half of the values proposed in the original method. The analyses were performed in triplicate for each distilling time x sample mass binomial, making a total of 12 tests, which were performed on the same day. The significance of the effects of the different distillation times and sample mass were evaluated by applying one-factor analysis of variance (ANOVA). For a 95\% confidence limit, it was found that the proposed amendments to the distillation time, sample mass, and the interaction between distilling time $x$ sample mass were not significant $(p>0.05)$ in determining the $\mathrm{SO}_{2}$ content in passion fruit juice. In view of the results that were obtained it was concluded that for integral passion fruit juice it was possible to reduce the distillation time and the sample mass in determining the $\mathrm{SO}_{2}$ content by the Monier-Williams method without affecting the result.
\end{abstract}

Keywords: sulfur dioxide; analytical methods; passion fruit juice; sulfites; design of experiments.

Practical Application: This study can be applied in analyses of sulfur dioxide in juices with reduced amounts of time and quantities of samples.

\section{Introduction}

Sulfites, or sulfite agents, are additives that release sulfur dioxide $\left(\mathrm{SO}_{2}\right)$ in conditions of use. They have various functions, such as antimicrobial agents, enzyme inhibitors, antioxidants, controlling enzymatic and non-enzymatic browning reactions, and in the modification of the structure and functional properties of proteins; their main function is as conservatives or antioxidants in foods and beverages (Walker, 1985; Fazio \& Warner, 1990; Wedzicha, 1992; Machado et al., 2006).

Permitted sulfite agents include sulfur dioxide and sulfite salts such as sodium/potassium metabisulfite and sodium/potassium/ calcium bisulfite. These are extensively used in the processing of foods and beverages because, apart from the aforementioned reasons, they are cheap, effective and versatile (Walker, 1985).

Sulfites may be present in foods in three different forms: free sulfite, which is not bound to the food molecules; reversibly-bound, which is released under certain $\mathrm{pH}$ and temperature conditions; and sulfite that is irreversibly-bound to foods (Walker, 1985; World Health Organization, 2009).

Reversibly-bound sulfites are formed when foods contain high amounts of glucose, xylose and L-xylose, arabinose, galacturonic acid, acetaldehyde, pyruvic acid and 2-ketoglutaric acid. Irreversibly-bound sulfites are formed when the matrix contains greater numbers of alkenes and aromatic compounds
(Nisida, 1991; Swales \& Wedzicha, 1992; World Health Organization, 2009).

Despite its many positive functions, $\mathrm{SO}_{2}$ intake can cause some adverse effects in sensitive individuals, such as breathing difficulties, gastric irritation and the induction of asthmatic reactions (Fazio \& Warner, 1990; Taylor \& Hefle, 2001; Vally et al., 2009). In 1974, the Joint FAO/WHO Expert Committee on Food Additives (JECFA) established an acceptable daily intake (ADI) for sulfites of $0-0.7 \mathrm{mg} / \mathrm{kg}$ body weight, expressed as $\mathrm{SO}_{2}$ (World Health Organization, 1974). Consequently, the quantification of $\mathrm{SO}_{2}$ in different commercial products is extremely important.

Resolution $n^{\circ} 04 / 88$ of the National Health Council of the Brazilian Ministry of Health established the maximum limit of sulfites in fruit juices and nectars as $0.02 \mathrm{~g} / 100 \mathrm{~g}$ or $\mathrm{g} / 100 \mathrm{~mL}$, expressed as residual $\mathrm{SO}_{2}$ for conservation purposes (Brasil, 1988). For cashew juice, Resolution RDC $\mathrm{n}^{\circ}$ 12/02 of the ANVISA/MS established a limit of $0.30 \mathrm{~g} / 100 \mathrm{~mL}$ for juice with high pulp content (dilution of 1:9) and a limit of $0.033 \mathrm{~g} / 100 \mathrm{~mL}$ for juice that is ready for consumption (Brasil, 2002). These limits were amended by Resolution $R D C n^{\circ} 08 / 13$ to $0.005 \mathrm{~g} / 100 \mathrm{~g}$ or $\mathrm{g} / 100 \mathrm{~mL}$ for juices, nectars, fruit pulps and tropical juices except for cashew pulp and cashew integral juice, where the maximum limit is $0.02 \mathrm{~g} / 100 \mathrm{~mL}$ for antioxidative properties. According to this technical regulation, in the case 
of concentrated or dehydrated juices, the dilution's factor must be considered for result comparison with the maximum limit established. Companies have a period of two years to adapt to this technical regulation (Brasil, 2013).

Thus, it can be seen that it is necessary to control this additive in foods, and particularly in beverages, because of its greater intake compared to other foods. One of the ways of monitoring this additive is the Monier-Williams method, which was developed in 1927, and has been widely used both in industry and in research centers because it is simple to implement, low-cost, stable and applicable to many matrices (Leclercq et al., 2000; Suh et al., 2007; Machado et al., 2008; Cressey \& Jones, 2009). In addition, the Monier-Williams method can be used as a reference to compare the accuracy and precision of other methods (Holak \& Specchio, 1989; Perfetti et al., 1989; Kim et al., 1990; Lawrence et al., 1990; Sullivan et al., 1990; Pizzoferrato et al., 1998; Lowinsohn \& Bertotti, 2001). These factors enable this method to be routinely used in quality control laboratories (Fazio \& Warner, 1990; Machado et al., 2008). Moreover, it is a classic method that is used as a reference by the Association of Official Analytical Chemists (2012), US Food and Drug Administration - FDA (CFR Title 21, Appendix A to Part 101; Food and Drug Administration, 1985), European Union (EN 1988-1;1998, European Food Safety Authority, 2013), and the Brazilian Ministry of Agriculture, Livestock and Supply (Brasil, 2005), as well as being widely used by public health laboratories and food industries. The Monier-Williams method determines the levels of free sulfite and reversibly-bound sulfite efficiently and with high levels of repeatability. However, one of the drawbacks of this method is its practical application because its distillation time can take up to 2 hours.

In order to improve the Monier-Williams method, the present study evaluated the effect of distillation time and sample mass reduced to half of the values proposed in the original method, on the level of sulfur dioxide in integral passion fruit juice (Passiflora sp).

\section{Materials and methods}

\subsection{Fruit sample}

A commercial nationwide-marketed integral passion fruit juice (Passiflora sp) was used in the experiments. The samples (two PET bottles of $500 \mathrm{~mL}$ ) were purchased in a local market in the city of São Paulo, Brazil, and they contained sodium metabisulfite (INS 223) in the ingredients list. As stated on the label, the dilution's factor 9 should be used in juice reconstitution with water. The bottles of juice were well mixed and homogenized and the mixture was kept in a closed $1 \mathrm{~L}$ plastic bottle until chemical analysis.

\subsection{Design of experiment and physicochemical analysis}

A $2^{2}$ full factorial design with three replications in the center point was used to assess the impact of distillation time and sample mass (independent variables) on the content of sulfur dioxide in integral passion fruit juice (dependent variable). The experiment was conducted in a completely randomized fashion (Table 1) in order to avoid carry-over effects (Rodrigues
\& Iemma, 2009). The analyses were performed in triplicate for each distilling time $\mathrm{x}$ sample mass binomial (105 min and $25 \mathrm{~g}$; $105 \mathrm{~min}$ and $50 \mathrm{~g} ; 50 \mathrm{~min}$ and $25 \mathrm{~g} ; 50 \mathrm{~min}$ and $50 \mathrm{~g}$ ), which resulted in a total of 12 trials that were performed on the same day under repeatability conditions.

This experiment evaluated the distillation time and sample mass, which were reduced to half of the values proposed by the $\mathrm{M}-\mathrm{W}$ method. For the sulfur dioxide analysis, a modified version of the Monier-Williams method was used, as referenced by Nagato et al. (2013) and the Association of Official Analytical Chemists (2012), which established a sample mass of $50 \mathrm{~g}$ and a total distillation time of $120 \mathrm{~min}$ (105 min of boiling) as reference experimental conditions to quantify the sulfur dioxide in beverages. The integral juice was also characterized with regard to $\mathrm{pH}$ value, soluble solids content ( $\left.{ }^{\circ} \mathrm{Brix}\right)$ and total acidity expressed as citric acid (g/100 g) using the methods described by Instituto Adolfo Lutz (2005a, b, c).

\subsection{Statistical analysis}

Experimental results were initially evaluated for normality and homogeneity of variances using the Shapiro-Wilk's test and Levene's test, respectively. Finally, the significance of the effects of the different distillation times and sample masss were evaluated by applying one-factor analysis of variance (ANOVA) (Granato et al., 2014). A Pareto chart was generated to show the statistical significance of the factors on the response (Statsoft, 2013). All statistical analysis was performed using the Statistica v.11 software (Statsoft, Tulsa, USA).

\section{Results and discussion}

The physicochemical characterization of the commercial integral passion fruit juice showed $11.3^{\circ} \mathrm{Brix}, \mathrm{pH} 3.0$ and $2.54 \mathrm{~g} / 100 \mathrm{~g}$ total acidity expressed as citric acid. The results of the $\mathrm{SO}_{2}$ concentration in juice in relation to the independent variables (factors) ranged from $0.0212-0.0224 \mathrm{~g} / 100 \mathrm{~g}$, as shown in Table 2.

Table 1. Design of experiment proposed to assess the distillation time and sample mass in the determination of sulfur dioxide in integral yellow passion fruit juice.

\begin{tabular}{ccccc}
\hline \multirow{2}{*}{$\begin{array}{c}\text { Order of } \\
\text { analysis }\end{array}$} & \multicolumn{2}{c}{ Coded values } & \multicolumn{2}{c}{ Real values } \\
\cline { 2 - 5 } & $\begin{array}{c}\text { Distiling } \\
\text { time }\left(\mathrm{x}_{1}\right)\end{array}$ & $\begin{array}{c}\text { Sample mass } \\
\left(\mathrm{x}_{2}\right)\end{array}$ & $\begin{array}{c}\text { Distiling } \\
\text { time }(\mathrm{min})\end{array}$ & $\begin{array}{c}\text { Sample mass } \\
(\mathrm{g})\end{array}$ \\
\hline 6 & 1 & -1 & 105 & 25 \\
10 & 1 & -1 & 105 & 25 \\
4 & 1 & 1 & 105 & 50 \\
11 & -1 & 1 & 50 & 50 \\
8 & 1 & 1 & 105 & 50 \\
5 & -1 & -1 & 50 & 25 \\
12 & 1 & 1 & 105 & 50 \\
3 & -1 & 1 & 50 & 50 \\
9 & -1 & -1 & 50 & 25 \\
2 & 1 & -1 & 105 & 25 \\
7 & -1 & 1 & 50 & 50 \\
1 & -1 & -1 & 50 & 25 \\
\hline
\end{tabular}


According to the statistical results (one-way ANOVA), for a $95 \%$ confidence limit, it was found that the proposed amendments to distillation time $(\mathrm{p}=0.056)$, sample mass $(\mathrm{p}=0.757)$ and interaction between distilling time $\mathrm{x}$ sample mass $(\mathrm{p}=0.477)$ were not significant in the determination of the $\mathrm{SO}_{2}$ content in passion fruit juice. The Pareto chart (Figure 1) that was generated from the experimental results clearly shows the isolated effect of the distillation time and the sample mass, as well as the interaction of distilling time $\mathrm{x}$ sample mass on the level of $\mathrm{SO}_{2}$ content in integral passion fruit juice.

These results show that reducing the distillation time and using smaller samples may be adopted to quantify the level of $\mathrm{SO}_{2}$ in integral passion fruit juice. This can be explained by the type of connection that the $\mathrm{SO}_{2}$ makes with the matrix components (Walker, 1985).

Several studies evaluated some slight experimental modifications in the Monier-Williams method such as: the use of other acids and indicators, apparatus used in the distillation procedure,

Table 2. Sulfur dioxide content in relation to distilling time and sample mass.

\begin{tabular}{cccc}
\hline $\begin{array}{c}\text { Order of } \\
\text { analysis }\end{array}$ & $\begin{array}{c}\text { Distilling time } \\
(\mathrm{min})\end{array}$ & $\begin{array}{c}\text { Sample mass } \\
(\mathrm{g})\end{array}$ & $\begin{array}{c}\mathrm{SO}_{2} \\
(\mathrm{~g} / 100 \mathrm{~g})\end{array}$ \\
\hline 6 & 105 & 25 & 0.0217 \\
10 & 105 & 25 & 0.0220 \\
4 & 105 & 50 & 0.0224 \\
11 & 50 & 50 & 0.0216 \\
8 & 105 & 50 & 0.0218 \\
5 & 50 & 25 & 0.0214 \\
12 & 105 & 50 & 0.0216 \\
3 & 50 & 50 & 0.0216 \\
9 & 50 & 25 & 0.0218 \\
2 & 105 & 25 & 0.0219 \\
7 & 50 & 50 & 0.0212 \\
1 & 50 & 25 & 0.0217 \\
\hline
\end{tabular}

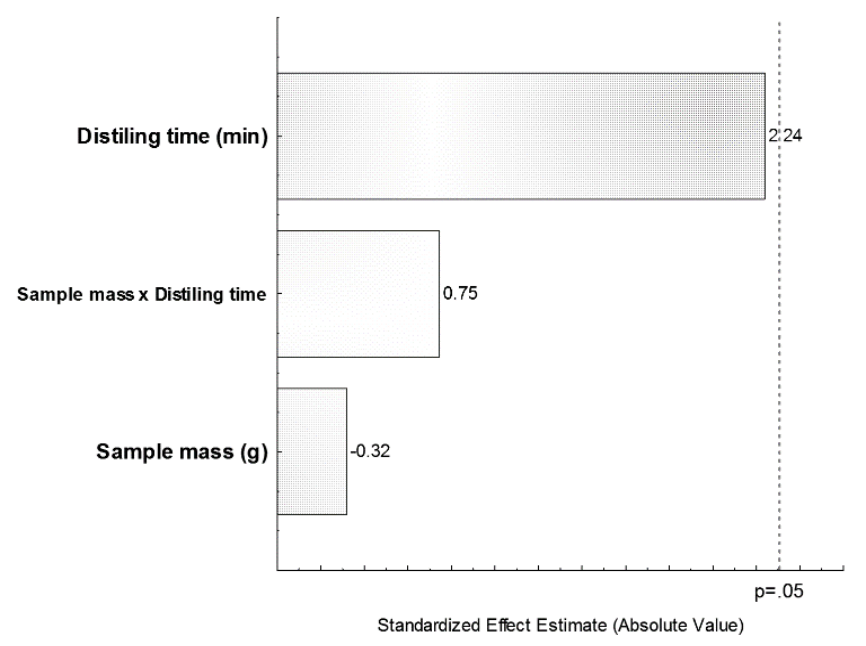

Figure 1. Pareto chart showing the non-significance of the distillation time and sample mass on the sulfur dioxide content of integral passion fruit juice. titrant concentration $(\mathrm{NaOH})$ and treatment of the sample prior to distillation (Yabiku et al., 1987; Lafeuille et al., 2007; Cressey \& Jones, 2009; Nagato et al., 2013). However, our work contributed to the literature by showing the effects of sample mass and distilling time on the sulfur dioxide analysis. Thus, for the official Monier-Williams method to be modified in terms of reduced sample mass and distillation time, a study of the impact of all the effects, both alone and combined (distillation time $\mathrm{x}$ sample mass) must be performed. If there is statistical significance $(\mathrm{p}<0.05)$, i.e. in the sample mass, the distillation time, or the interaction between the distillation time and the sample mass, it is recommended that the conventional Monier-Williams method is used without alterations.

The residual $\mathrm{SO}_{2}$ level (0.0212-0.0224 g/100 g) obtained for integral passion fruit juice indicated that the current use of sulphites by industry was well below the value legally permitted by the Brazilian legislation $(0.005 \mathrm{~g} / 100 \mathrm{~g})$ considering the dilution factor (9) for juice reconstitution.

\section{Conclusions}

This study showed that it was possible to alter the distillation time and sample mass in terms of $\mathrm{SO}_{2}$ analysis using the Monier-Williams method for the analysis of integral passion fruit juice. These modifications are of great importance, especially for public health laboratories, which use this method as a reference, and where time and the amount of sample available for analysis are critical factors.

It is important to stress that this modification was possible for this particular matrix, but depending on the composition of other types of food/drinks there may be a greater or lesser interaction between sulfite salts with the intrinsic matrix components. For that reason, studies of the variables (distilling time $\mathrm{x}$ sample mass) in each case are necessary. The current work showed, for the first time in the literature, an experimental design combined with statistical analysis for the assessment of the effects of each factor to be modified in the official Monier-Williams method.

\section{References}

Association of Official Analytical Chemists - AOAC. (2012). Official methods of analysis of the Association of Official Analytical Chemists (19th ed., Chap. 47, pp. 33-35). Gaithersburg: AOAC. (Method 990.28).

Brasil, Ministério da Saúde. (1988, December 19). Aprova a revisão das tabelas I, III, IV e V referente a aditivos intencionais, bem como os anexos I, II, III, IV e VII todas do Decreto $n^{\circ} 55871$, de 26 de março de 1965 (Resolução CNS/MS nº4, de 24 de novembro de 1988). Diário Oficial [da] República Federativa do Brasil.

Brasil, Agência Nacional de Vigilância Sanitária. (2002, January 10). Aprova a extensão de uso do aditivo INS 220 dióxido de enxofre na função de conservador para suco de caju (Resolução RDC n 12, de 10 de janeiro de 2002). Diário Oficial [da] República Federativa do Brasil.

Brasil, Ministério da Agricultura, Pecuária e Abastecimento. (2005, September 20). Aprova o Manual Operacional de Bebidas e Vinagres (Instrução Normativa $n^{\circ} 24$ de 8 de setembro de 2005). Diário Oficial [da] República Federativa do Brasil.

Brasil, Agência Nacional de Vigilância Sanitária. (2013, February 21). Dispõe sobre a aprovação de uso de aditivos alimentares para produtos 
de frutas e de vegetais e geléia de mocotó (Resolução RDC n 08, de 06 de março de 2013). Diário Oficial [da] República Federativa do Brasil.

Cressey, P., \& Jones, S. (2009). Levels of preservatives (sulfite, sorbate and benzoate) in New Zealand foods and estimated dietary exposure. Food Additives and Contaminants, 26(5), 604-613. http://dx.doi. org/10.1080/02652030802669188. PMid:19680935.

European Food Safety Authority - EFSA. (2013). Analysis of needs in post-market monitoring of food additives and preparatory work for future projects in this field (External Scientific Report, EN-419, pp. 1-26). Parma: European Food Safety Authority. Retrieved from http:// www.efsa.europa.eu/en/supporting/doc/419e.pdf

Fazio, T., \& Warner, C. R. (1990). A review of sulphites in foods: analytical methodology and reported findings. Food Additives and Contaminants, 7(4), 433-454. http://dx.doi.org/10.1080/02652039009373907. PMid:2203650.

Food and Drug Administration - FDA. (1985). Appendix A to part 101 - Monier-Williams procedure (with modifications) for sulfites in food. Center for Food Safety and Applied Nutrition, Food and Drug Administration. Spring: FDA. Retrieved from http://www.accessdata.fda. gov/scripts/cdrh/cfdocs/cfcfr/CFRSearch.cfm?an=21:2.0.1.1.2.7.1.4.1

Granato, D., Calado, V. A. M., \& Jarvis, B. (2014). Observations on the use of statistical methods in food science and technology. Food Research International, 55, 137-149. http://dx.doi.org/10.1016/j. foodres.2013.10.024.

Holak, W., \& Specchio, J. (1989). Determination of sulfites in foods by simultaneous nitrogen purging and differential pulse polarography. Journal of Association of Official Analytical Chemists, 72(3), 476-480. PMid:2745373.

Instituto Adolfo Lutz - IAL. (2005a). Procedimentos e determinações gerais. In Instituto Adolfo Lutz - IAL. Métodos físico-químicos para análise de alimentos (4 th ed., Chap. 4, pp. 104-105). Brasília: ANVISA.

Instituto Adolfo Lutz - IAL. (2005b). Conservas vegetais, frutas e prudutos de frutas. In Instituto Adolfo Lutz - IAL. Métodos físico-químicos para análise de alimentos (4th ed., Chap. 15, pp. 577-578). Brasília: ANVISA.

Instituto Adolfo Lutz - IAL. (2005c). Conservas vegetais, frutas e prudutos de frutas. In Instituto Adolfo Lutz - IAL. Métodos físico-químicos para análise de alimentos (4th ed., Chap. 15, pp. 579-581). Brasília: ANVISA.

Kim, H.-J., Conca, K. R., \& Richardson, M. J. (1990). Determination of sulfur dioxide in grapes: comparison of the Monier-Williams method and two ion exclusion chromatographic methods. Journal of Association of Official Analytical Chemists, 73(6), 983-989. PMid:2289930.

Lafeuille, J.-L., Lefevre, S., \& Achouri, D. (2007). Determination of added sulfites in dried garlic with a modified version of the optimized Monier-Williams method. Journal of AOAC International, 90(4), 1090-1097. PMid:17760347.

Lawrence, J. F., Chadha, R. K., \& Ménard, C. (1990). Comparison of three liquid chromatographic methods with FDA optimized MonierWilliams method for determination of total sulfite in foods. Journal of Association of Official Analytical Chemists, 73(1), 77-79. PMid:2312516.

Leclercq, C., Molinaro, M. G., Piccinelli, R., Baldini, M., Arcella, D., \& Stacchini, P. (2000). Dietary intake exposure to sulphites in Italy - analytical determination of sulphite-containing foods and their combination into standard meals for adults and children. Food Additives and Contaminants, 17(12), 979-989. http://dx.doi. org/10.1080/02652030010014402. PMid:11271844.

Lowinsohn, D., \& Bertotti, M. (2001). Determination of sulphite in wine by coulometric titration. Food Additives and Contaminants, 18(9), 773-777. http://dx.doi.org/10.1080/02652030117536. PMid:11552744.

Machado, R. M. D., Toledo, M. C. F., \& Vicente, E. (2006). Sulfitos em alimentos. Brazilian Journal of Food Technology, 9(4), 265-275.

Machado, R. M. D., Toledo, M. C. F., Almeida, C. A. S., \& Vicente, E. (2008). Analytical determination of sulphites in fruit juices avaliable on the Brazilian market. Brazilian Journal of Food Technology, 11(3), 226-233.

Nagato, L. A. F., Takemoto, E., Della Torre, J. C. M., \& Lichtig, J. (2013). Verificação do método de Monier-Williams otimizado na determinação de dióxido de enxofre em sucos de frutas, água de coco e cogumelo em conserva. Revista do Instituto Adolfo Lutz, 72(1), 34-48.

Nisida, A. L. A. C. (1991). Fatores envolvidos na sulfitação/dessulfitação de sucos. Coletânea ITAL, 21(1), 12-19.

Perfetti, G. A., Joe, F. L. Jr, \& Diachenko, G. W. (1989). Liquid chromatographic determination of sulfite in grapes and selected grape products. Journal of Association of Official Analytical Chemists, 72(6), 903-906. PMid:2592311.

Pizzoferrato, L., Di Lullo, G., \& Quattrucci, E. (1998). Determination of free, bound and total sulphites in foods by indirect photometry HPLC. Food Chemistry, 63(2), 275-279. http://dx.doi.org/10.1016/ S0308-8146(98)00021-1.

Rodrigues, M. I., \& Iemma, A. F. (2009). Planejamento de experimentos e otimização de processos (2nd ed.). Campinas: Casa do Espírito Amigo Fraternidade Fé e Amor.

Statsoft (2013). Eletronic statistics textbook: experimental design: science, industrial DOE. Tulsa: Statsoft Inc. Retrieved from http://www.statsoft. com/Textbook/Experimental-Design

Suh, H.-J., Cho, Y.-H., Chung, M.-S., \& Kim, B. H. (2007). Preliminary data on sulphite intake from the Korean diet. Journal of Food Composition and Analysis, 20(3-4), 212-219. http://dx.doi.org/10.1016/j.jfca.2006.04.012.

Sullivan, J. J., Hollingworth, T. A., Wekell, M. M., Meo, V. A., Saba, H. H., Etemad-Moghadam, A., Eklund, C., Phillips, J. G., \& Gump, B. H. (1990). Determination of total sulfite in shrimp, potatoes, dried pineapple, and white wine by flow injection analysis: collaborative study. Journal of Association of Official Analytical Chemists, 73(1), 35-42. PMid:2312511.

Swales, S., \& Wedzicha, B. L. (1992). Kinetics of the sulphite-inhibited browning of fructose. Food Additives and Contaminants, 9(5), 479483. http://dx.doi.org/10.1080/02652039209374100. PMid:1298652.

Taylor, S. L., \& Hefle, S. L. (2001). Food allergies and other food sensitivities. Food Technology, 55(9), 68-82.

Vally, H., Misso, N. L. A., \& Madan, V. (2009). Clinical effects of sulphite additives. Clinical and Experimental Allergy, 39(11), 1643-1651. http:// dx.doi.org/10.1111/j.1365-2222.2009.03362.x. PMid:19775253.

Walker, R. (1985). Sulphiting agents in foods: some risk/benefit considerations. Food Additives and Contaminants, 2(1), 5-24. http:// dx.doi.org/10.1080/02652038509373522. PMid:4018315.

Wedzicha, B. L. (1992). Chemistry of sulphiting agents in food. Food Additives and Contaminants, 9(5), 449-459. http://dx.doi. org/10.1080/02652039209374097. PMid:1298649.

World Health Organization - WHO (1974). Toxicological evaluation of some foods additives including anti-caking agents antimicrobials, antioxidants, emulsifiers and thickening agents (WHO Food Additive Series, No. 5). Geneva: WHO.

World Health Organization - WHO (2009). Safety evaluation of certain food additives (Food Additives Series, No. 60). Geneva: WHO.

Yabiku, H. Y., Takahashi, M. Y., Martins, M. S., Heredia, R., \& Zenebon, O. (1987). Níveis de conservadores intencionais em sucos naturais de frutas comercializados no Brasil. Revista do Instituto Adolfo Lutz, $47(1 / 2), 65-75$. 